\title{
PAPPA wt Allele
}

National Cancer Institute

\section{Source}

National Cancer Institute. PAPPA wt Allele. NCI Thesaurus. Code C91824.

Human PAPPA wild-type allele is located in the vicinity of $9 q 33.2$ and is approximately 249

$\mathrm{kb}$ in length. This allele, which encodes pappalysin-1 protein, plays a role in both

pregnancy and the mediation of proteolysis. 